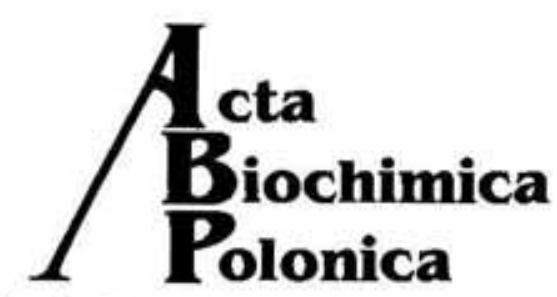

Vol. 43 No. 2/1996

$305-312$

QUARTERLY

Lecture delivered at the Symposium on "Progress in Tumor Biology" held in Gliwice (Poland) on 13-14 October, 1995

\title{
DNA adducts in environmental, occupational and life-style studies in human biomonitoring*
}

\author{
Kari Hemminki ${ }^{a}$, Ewa Grzybowska ${ }^{b}$, Piotr Widłak ${ }^{b}$ and Mieczysław Chorąży \\ ${ }^{a}$ Department of Bioscience at Novum, Karolinska Institute, 14157 Huddinge, Sweden \\ ${ }^{\mathrm{b}}$ Department of Tumor Biology, Institute of Oncology, 44-100 Gliwice, Poland
}

Key words: DNA adducts; protein adducts; mutations; environmental and occupational exposure; styrene; tobacco; biomonitoring

\begin{abstract}
The importance of DNA adducts in carcinogenesis has been discussed. The ${ }^{32} \mathrm{P}$-postlabelling method was developed as a quantitative technique to measure the level of different DNA adducts including adducts in human DNA. The elevated level of DNA adducts was found in white blood cells in persons exposed environmentally and occupationally to high concentrations of PAHs (polycyclic aromatic hydrocarbons) in the ambient air. Tobacco also generated higher level of DNA adducts both in lymphocytes and laryngeal tissues of smokers. Exposure to styrene has been of interest world-wide because of the very high exposure and persistence of adducts in DNA of lamination workers.
\end{abstract}

\section{WHY DNA ADDUCTS ARE IMPORTANT?}

During the 15 years when DNA adduct studies have been possible in humans (IARC, 1994) the question about their significance has been asked. There is no direct answer to the question but a lot of 'circumstantial evidence points to their mechanistic role in cancer (Hemminki, 1993). Unrepaired adducts in DNA can induce mutations which are believed to be the initiation step in carcinogenesis. Adducts generating cross-links can stimulate the cell proliferation and contribute in that way to carcinogenesis too. The direct evidence of the role of DNA adducts in carcinogenesis is lacking and it would be simplistic to assume that one measurement in time would tell much about the risk. However, if a particular exposure has lasted for an extended period of time, or if has been excessive, such as anticancer chemotherapy or an accident with radioactive material, some risk may be predicted. Adducts appear in DNA soon after the exposure reflecting present DNA damage. They are also useful in the identification of the active ingredients of the complex mixtures. Although the action of adducts in DNA is emphasized in "initiation" phase of carcinogenesis, the recent evidence on genetic lesions in multiple steps of cancer development, suggest that DNA damage has a role in many stages of oncogenesis what is especially important in the assessment of hazards coming from the environmental carcinogens where the exposure is constant.

The project was supported by the OK Environment Fund and the Work-Environment Fund., the EU Environment program, partly through the Swedish Medical Research Council, the National Environmental Protection Board and the Swedish Cancer Fund and the EU PECO program.

Abbreviations: GSTM1, glutathione transferase; HPRT, hypoxanthine guanine phosphoribosyl transferase; NAT2, $\mathrm{N}$-acetyltransferase; $\mathrm{PAH}$, polycyclic aromatic hydrocarbons. 


\section{DEVELOPMENT OF THE ${ }^{32}$ P-POSTLABEL- LING METHOD}

The ${ }^{32} \mathrm{P}$-postlabelling method, introduced about 15 years ago made it possible for the first time to analyze DNA-adducts existing in DNA in vivo. The method has been extensively used to compare adduct patterns in various tissues and in various exposures. Most studies have focused on unidentified aromatic adducts because the original technique selects for these types of adducts (Hemminki, 1995). Our main contributions in this area have been, by introducing standard compounds, 1) to focus on the identification of adducts and 2) to introduce the principles of quantification of adducts (Vodicka et al., 1991; Hemminki et al., 1991a, b). Although this is widely accepted now, it was long thought by a large section of the groups analyzing DNA adducts by postlabelling method that labelling of all adducts is complete. By now, we and others have demonstrated with tens of different synthetic postlabelling standards that, depending of the adducts and conditions of labelling, the recoveries vary between 0 to $100 \%$. Even diastereomers can label differently (Hemminki et al., 1991a). In an illustrative experiment, DNA adducts of a number of ${ }^{3} \mathrm{H}$-labelled polycyclic aromatic hydrocarbons (PAH) were prepared in a microsomal system and used for optimisation and measurements of recoveries in the postlabelling assay. The optimal labelling conditions for all tested compounds were very similar. The recoveries varied from 3 to $60 \%$ among different PAHs indicating that the levels of these adducts could be considerably underestimated when analyzing human samples from PAH exposed populations (Segerbäck \& Vodicka, 1993). As we have found similar results with an entirely different group of compounds, it can be generally concluded that different adducts require different conditions for optimal labelling (Kumar et al., 1995). Thus the absence of proper standards, or unknown adducts, make quantitative interpretation of the postlabelling results difficult, if not impossible. The quantitative postlabelling can be done for known adducts only if their stability, labelling efficiency and total recovery were tested.
In our laboratory the aim has been to scale down the assay to reduce the amount of radioactivity handled and the costs in general. The assay is now run in $2 \mu \mathrm{l}$ with about $1 / 10$ of the radioactivity used by most other laboratories. Parameters of the postlabelling assay including the concentrations of enzymes, salts incubation times etc. were optimized (Vaca et al., 1992; Szyfter et al., 1994a).

\section{AROMATIC ADDUCTS}

In spite of the above problems in the interpretation of postlabelling results of complex mixtures, the group has been involved in a number of studies where PAHs are the principal exposures. Also many of the groups studied have been at a risk of cancer according to epidemiological studies that reflect exposures a few decades ago. The main questions posed have been: 1) do the exposed groups show higher, work-related adduct levels than the controls; 2 ) is there a correlation between exposure measures (air concentration or urinary 1-hydroxypyrene) and adducts; 3 ) how large are the individual variations and metabolic genotypes on the level of adducts. All the human studies have been carried out on coded blood cell samples.

\section{Occupational populations}

The studied populations have included foundry and coke workers, aluminium and electrode workers and chimney sweeps. Additionally, some other occupational groups have been studied as reference groups in environmental studies, are discussed below. The foundry study has involved blood and urine sampling of the same individuals each December for four years. The last sampling was done December, 1993. It is a multi-endpoint study, including some 15 parameters. Only results from the two first years on certain outcomes have been published but an intense compilation of the total material is underway. The first published papers showed elevated total white blood cell DNA adduct levels measured by immunoassay (Santella et al., 1993) and postlabelling (Perera et al., 1994), relating to exposure. HPRT (gene coding the hypoxanthine guanine phosphoribosyl transferase) mutations correlated with exposure and adduct levels while 
glycophorin A NO (the major cell surface sialoglycoprotein of human erythrocytes) mutations had a moderate trend with exposure (Perera et al., 1993, 1994). Among the other occupational groups coke workers had higher levels of aromatic adducts than the local controls (Grzybowska et al., 1993a). Somewhat elevated but not statistically significant differences were seen in electrode and aluminium workers even though air concentrations of PAHs and urinary 1-hydroxypyrene levels indicated excessive exposure (Ovrebö et al., 1994, 1995). Adduct levels were also slightly increased in total white blood cell DNA of chimney sweeps. However, the difference to a control group became significant only after adjustment for the CYP1A1 (cytochrome P450 monooxygenase gene) and glutathione transferase (GSTM1) genotype (Ichiba et al., 1994). Yet it should be pointed out that each of the genotype alone had a rather small effect on DNA adduct levels. In all the studies cited the interindividual variation in the levels of adducts has been large, over 10 -fold. The variation is usually larger in the exposed as compared to the control populations, indicating that exposures as well as constitutional factors contribute to such a variation.

\section{Environmentally exposed populations}

Two series of environmental studies have been carried, one in Poland and the other mainly in Sweden. The Polish study was initiated several years ago in response to the alarming reports on the environmental pollution in Silesia, a heavily industrialized area. The first study on the Silesian population showed an elevated level of adducts, by postlabelling and immunoassay, in the total white blood cells of the residents (Hemminki et al., 1990). This was followed by reports on seasonal differences in adduct levels, which matched the air concentrations of PAHs (Grzybowska et al., 1993a). The effects were mainly seen in DNA of the long-lived lymphocytes, while granulocytes showed no clear effect. Sampling in the summer and winter allowed a rough estimations of the half-live of aromatic adducts in lymphocytes to be 1-2 months (Grzybowska et al., 1993b, Fig. 1 and 2). Also cytogenetic damage was seen in the Silesian population (Perera et al., 1992).

The nature of the adducts detected by postlabelling has been studied in more detail by comparing nuclease P1, butanol extraction and immunoaffinity purification of the adducts.

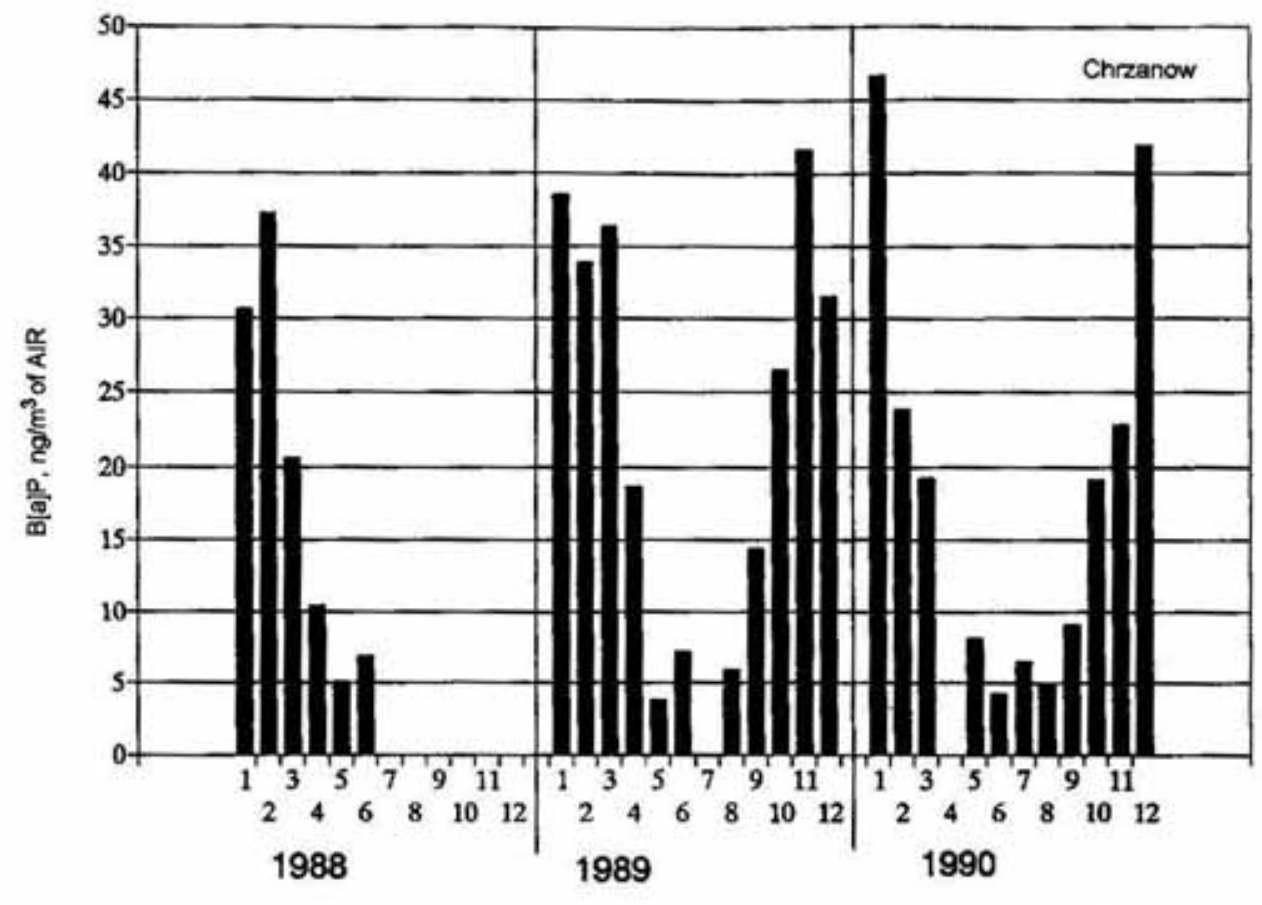

MonthYear

Fig. 1. Air concentrations of benzo(a)pyrene in Chrzanow between 1988-1990. Note the variation between summer and winter. 


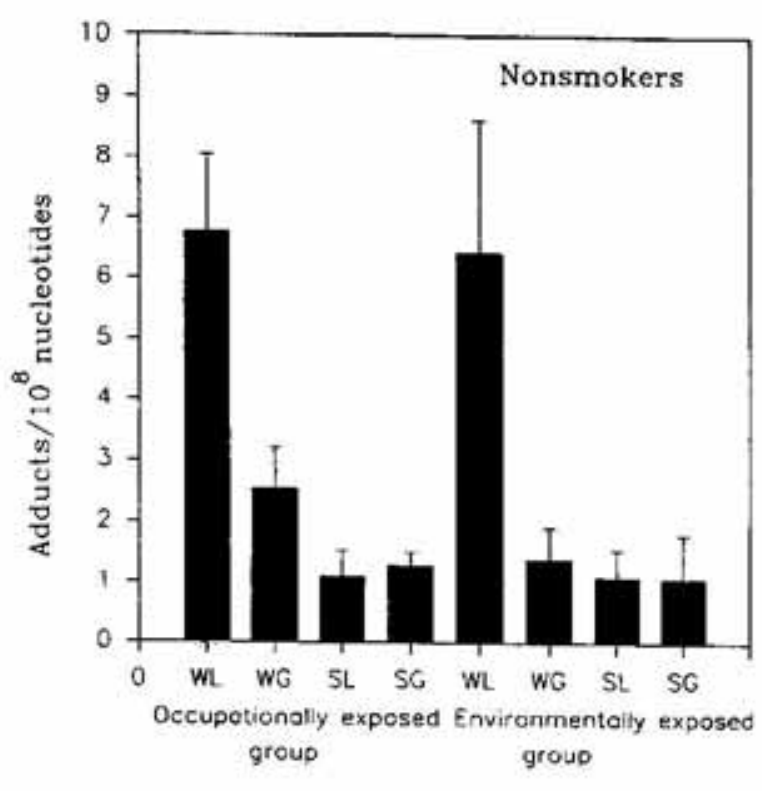

Fig.2. Aromaticadduct levels of non-smoking population in Silesia, occupationally or environmentally exposed to air pollution.

Blood cells were separated, WL winter lymphocytes; WG winter granulocytes; SL summer lymphocytes; SG summer granulocytes (Grzybowska et al., 1993b).

The adduct recovery was approximately equal by the P1 nuclease and butanol techniques, suggesting that the adduct are of PAH-type. For immunoaffinity chromatography an antibody raised against benzo(a)pyrene diol epoxideDNA was used. Only about $25 \%$ of the adducts were bound by the antibody, indicating that most of the adducts in DNA are not closely related to benzo(a)pyrene. However, in winter time of high air pollution the relative binding by the immunoaffinity column was higher than in the summer time (Widłak et al., 1996, Fig. 3). In HPLC analysis using flow-through radioac-

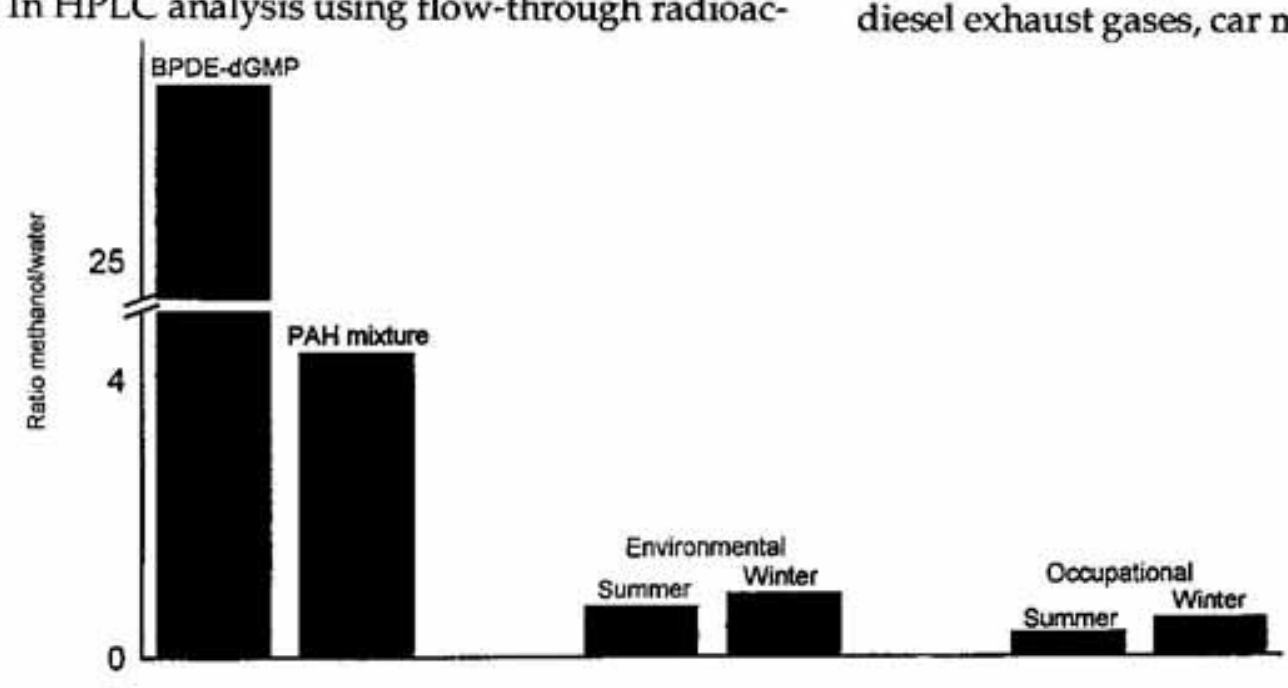

tivity detector typical seasonal adduct peaks were noted and they were particularly prominent in lymphocyte DNA collected in the winter time. They eluted in the area of PAHDNA adducts giving additional support that the adducts are PAH-like (Möller et al., 1996).

The Swedish (all well as some of the above) studies were carried out in the European Union Environment program. In the first study bus drivers from central Stockholm and from outskirts were selected. Taxi drivers were one reference group. As a non-occupational control group fine mechanics from Huddinge Hospital were used. All the participants were non-smokers. Aromatic DNA adducts in lymphocytes, $\mathrm{PAH}$ adducts in albumin and ethene and propene adducts in hemoglobin were not elevated in the urban bus drivers. However, both aromatic DNA adducts and PAH-albumin adducts were elevated in taxi drivers for an unexplained reason (Hemminki et al., 1994a, Fig. 4). A similar type of study has been carried out in Milan, Italy. The study subjects were newspaper vendors from busy streets and outskirts of Milan. The levels of DNA adducts did not differ in these populations. The analysis of PAH-hemoglobin adducts done for the same subjects showed the higher level of adducts in newspaper vendors from busy streets than from outskirts, however the difference was not statistically significant (Airoldi, unpublished results).

Some occupational groups, exposed to car and diesel exhaust, were positive controls in the above EU study. They included garage workers, overhauling diesel buses and inhaling diesel exhaust gases, car mechanics exposed to

Fig. 3. Fractions of aromatic DNA adducts in the immunoaffinity chromatography with the benzo(a)pyrene diol epoxide-DNA antibody, eluted in methanol (bound fraction) and in water (nonbound fraction) (Widtak et al., 1996). 
Adducts in drivers

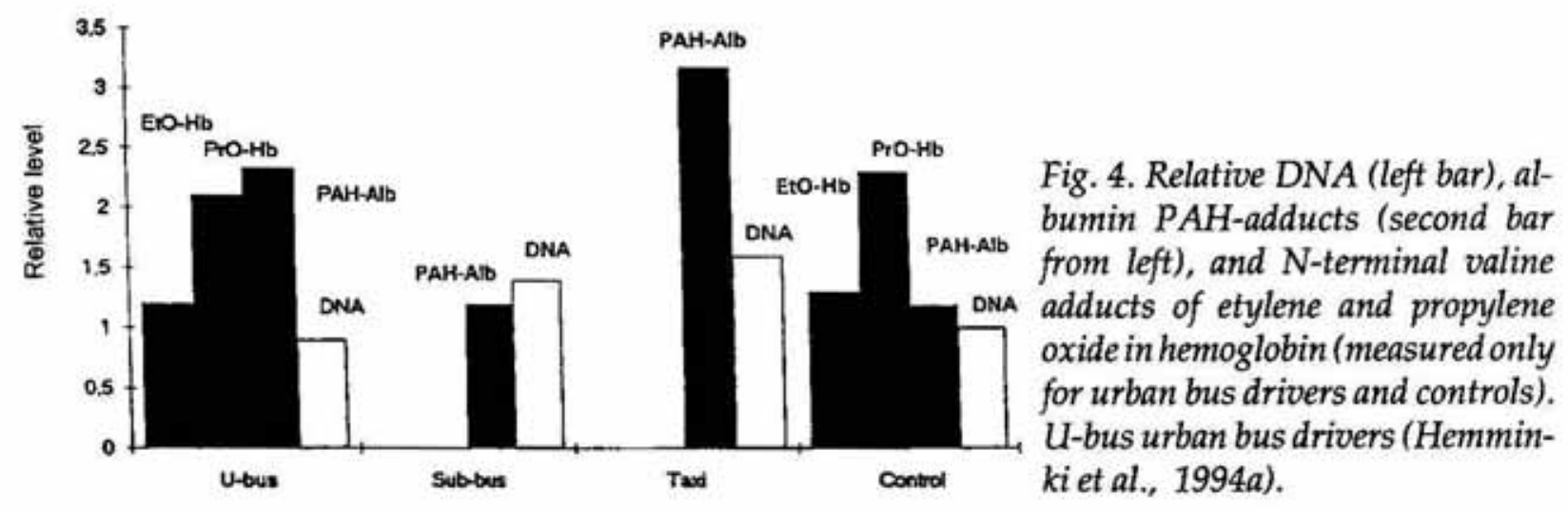

spill engine oils but not to exhausts, and truck terminal workers, unloading and reloading diesel trucks. All these groups had increased levels of lymphocyte DNA adducts, the highest levels being correlated with air concentrations of diesel exhausts. The estimated air benzo(a)pyrene levels were below $10 \mathrm{ng} / \mathrm{m}^{3}$ (Hemminki et al., 1994b, Fig. 5). The HPRT mutant frequency was not increased in garage workers but at an individual level there was a highly significant correlation between adducts and mutant frequency. GSTM1 and $\mathrm{N}$-acetyl transferase (NAT2) genotypes were determined in the study subjects. While the genotypes had no effect on HPRT mutant frequency, slow acetylators, lacking the GSTM1 gene, had the DNA adduct levels significantly higher (Hou et al., 1995).

\section{Tobacco}

Tobacco smoking, a main killer of human, has been used as a model in a number of studies. It was shown that the smokers had a higher aromatic adduct levels in lymphocytes as compared to granulocytes, which was the first indication that in chronic exposure the main focus should be on lymphocytes (Savela \& Hemminki, 1991). However, taking inconsideration the very different half-lives of lymphocytes and granulocytes, the separation of cells only clears off the noise caused by granulocytes and improves the precision as only about $25 \%$ of the DNA in total white blood cells is from lymphocytes. This should be an important principle applied in biomonitoring studies.

Smoking is a known risk factor of laryngeal cancer. Aromatic adduct of laryngeal tissue,

DNA adducts in bus garage workers

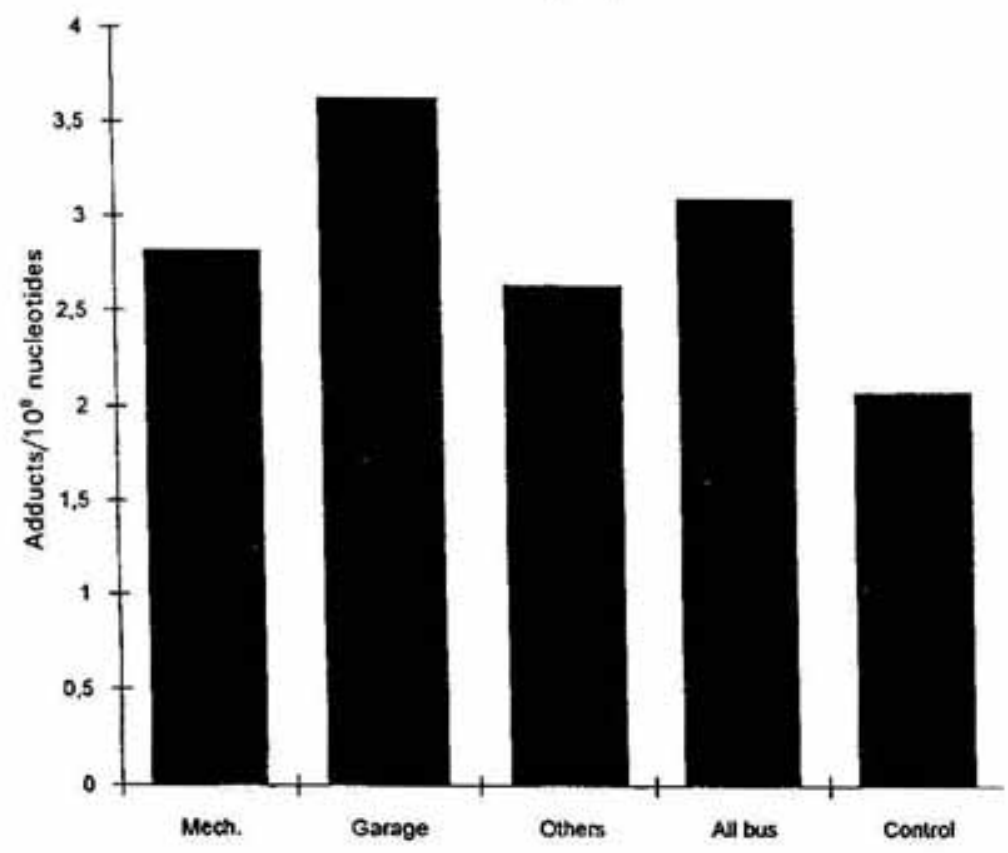

Fig. 5. Aromatic DNA adduct levels of bus maintenance personnel by type of employment, mechanics, garage and others (Hemminki et al., 1994b). The differences between all the groups, except for others, compared to controls are significant. 
obtained from operation, were analyzed and there was a relationship to smoking but most clearly in the tumor tissue. Both tumor and normal laryngeal tissues showed a correlation of about 0.9 to the total white blood cells (Szyfter et al., 1994b).

\section{STYRENE}

Genotoxicity of styrene has been of interest world-wide because it is one of the few suspected mutagenic compounds, which may cause daily exposures in gram quantities (Hemminki \& Vodicka, 1995). Styrene is an example on how the chemical characterization, fascinating in itself, lead to a production of standard compounds for postlabelling (Vodicka \& Hemminki, 1991) and to a quantification of O6-guanine adducts in white blood cell DNA of lamination workers (Vodicka et al., 1993). Further studies have been carried out to sample serially lamination workers and to isolate lymphocytes and granulocytes. Again it was shown that adduct are essentially only found in lymphocytes. The repair of O6-adducts appeared to be slow as no essential decrease in adduct levels were noted after a two week vacation (Vodicka et al., 1994).

HPRT mutation frequency was elevated in laminators exposed to styrene but the increase reached statistical significance only when compared to an external rather than factory control group. The adduct studies suggested that the factory controls in fact are not completely unexposed. Strand-breaks, measured by the Comet assay, were also increased in the lamination workers. There was a correlation between strand breaks and O6-guanine adducts, but neither correlated with HPRT mutant frequency (Vodicka et al., 1995). In vitro data on the effect of styrene oxide, main metabolite of styrene, on cultured human lymphocytes confirmed the relatively long half-lives of O6guanine DNA adducts and the induction of strand breaks. Induction of HPRT mutations was consider weak (Bastlova et al., 1995).

\section{ALKYLATION PRODUCTS}

Postlabelling method was adapted to the analysis 7-alkylguanine adducts of DNA by using pre-purification by ion exchange chromatography, as the commonly used nuclease $\mathrm{P} 1$ and butanol extraction techniques were not possible with small polar adducts (Mustonenet al., 1991a, b). The method was applied in human total white blood cells, where methylation products could be detected in all individuals but in those receiving procarbazine and dacarbazine the levels of adducts were over 20 times higher. (We now know that the 7-methylguanine adduct spot also contains 7-(2-hydroxyethyl)guanine adducts, which however are poorly labelled and contribute little to the radioactivity of the spot (Kumar \& Hemminki, 1996). Smokers had elevated levels of 7-methylguanine, particularly in their lymphocyte as compared to the granulocyte DNA (Mustonen \& Hemminki, 1992). The adduct levels were highest in the bronchial DNA of smokers, exceeding the level in non-smoker almost 4 times (Mustonen et al., 1993). In a small number of smokers both target (bronchial) and surrogate (lymphocyte) DNA were available, showing a correlation of 0.8 .

Larynx tissue samples obtained from operation have also been assayed for 7-methylguanine DNA adducts. There was a relationship to smoking, and larynx adduct levels exceeded those of white blood cells two times (Szyfter et al., 1996). There was a modest correlation only between 7 -alkylguanines and aromatic adduct (which were discussed above).

\section{CONCLUSIONS}

DNA adduct studies in humans are becoming more quantitative and therefore offer chances for quantitative risk estimation. As epidemiological studies always show the risks of exposure decades back, DNA and protein adduct studies can be used at the present day risk estimation. DNA adduct studies are likely to give clues to individual risks and may therefore provide the quantitative information about the present exposure to genotoxic agents in the environment.

The authors want to congratulate the senior author Professor Mieczysław Chorąży for his 70 th birthday. They are indebted to his insight 
in suggesting many of the environmental studies reported.

\section{REFERENCES}

Bastlova, T., Vodicka, P., Peterkova, K., Hemminki, K. \& Lambert, B. (1995) Styrene oxide-induced HPRT mutations and DNA strand breaks in cultured human T-lymphocytes. Carcinogenesis 16, 2357-2362.

Grzybowska, E., Hemminki, K. \& Chorąży, M. (1993a) Seasonal variations in levels of DNA adducts and $\mathrm{X}$-spots in the human populations living in different parts of Poland. Environ. Health Perspect. 99, 77-81.

Grzybowska, E., Hemminki, K., Szeliga, J. \& Chorąży, M. (1993b) Seasonal variation of aromatic adducs in human lymphocytes and granulocytes. Carcinogenesis 14, 2523-2526.

Hemminki, K., Grzybowska, E., Chorąży, M., Twardowska-Saucha, K., Sroczyríski, J.W., Putman, K.L., Randerath, K., Phillips, D.H., Hewer, A., Santella, R.M., Young, T.L. \& Perera, F.P. (1990) DNA adducts in humans environmentally exposed to aromatic compounds in an industrial area of Poland. Carcinogenesis 7, 1229-1231.

Hemminki, K., Szyfter, K. \& Kadlubar, F.F. (1991a) Quantitation of the ${ }^{32} \mathrm{P}$-postlabeling reaction using $\mathrm{N} 1, \mathrm{~N}^{2}$ and $\mathrm{C} 8$ modified deoxyguanosine $3^{\prime}$-monophosphates as substrates. Chem.-Biol. Interact. 77, 51-61.

Hemminki, K., Szyfter, K., Vodicka, P., Koivisto, P., Mustonen, R. \& Reunanen, A. (1991b) Quantitative aspects of ${ }^{32} \mathrm{P}$-postlabeling; in Trends in Biological Dosimetry (Gledhill, B.L. \& Mauro, F., eds.) pp. 219-228, John Wiley \& Sons, New York.

Hemminki, K., Söderling, J., Ericson, P., Norbeck, H.E. \& Segerbäck, D. (1994b), DNA adducts among personnel servicing and loading diesel vehicles. Carcinogenesis 15, 767-769.

Hemminki, K., Zhang, L.F, Kruger, J., Autrup, H., Törnqvist, M., Norbeck, H.E. (1994a) Exposure of bus and taxi drivers to urban air pollutants as measured by DNA and protein adducts. Toxicol. Lett. 72, 171-174.

Hemminki, K. (1993) DNA adducts, mutations and cancer. Carcinogenesis 14, 2007-2012.

Hemminki, K. (1995) DNA adducts in biomonitoring. J. Occup. Environ. Med. 37, 44-51.

Hemminki, K. \& Vodicka, P. (1995) Styrene: from characterisation of DNA adducts to application in styrene-exposed lamination workers. Toxicol. Lett. 77, 153-161.

IARC (1994) DNA adducts: Identification and biological significance (Hemminki, K., Dipple, A., Shuker,
D.E.G., Kadlubar, F.F., Segerbäck, D. \& Bartsch, H., eds.) IARC Sci. Publ. 125, Lyon.

Ichiba, M., Hagmar, L., Rannug, A., Högstedt, B., Alexandrie, A.-K., Carstensen, U. \& Hemminki, K. (1994) Aromatic DNA adducts, micronuclei and genetic polymorphism for CYP1A1 and GST1 in chimney sweeps. Carcinogenesis 15, 1347-1352.

Hou, S.-M., Lambert, B. \& Hemminki, K. (1995) Relationship between hprt mutant frequency, aromatic DNA adducts and genotypes for GSTM1 and NAT2 in bus maintenance workers. Carcinogenesis 16, 1913-1917.

Kumar, R., Staffas, J., Försti, A. \& Hemminki, K. (1995) ${ }^{32}$ P-Postlabelling method for the detection of 7-alkylguanine adducts formed by the reaction of different 1,2-alkyl epoxides with DNA. Carcinogenesis 16, 483-489.

Kumar, R. \& Hemminki, K. (1996) Separation of 7-methyl and 7-(2-hydroxyethyl)-guanine adducts in human DNA samples using a combination of TLC and HPLC. Carcinogenesis 17, 485-492.

Mustonen, R., Hietanen, P. \& Hemminki, K. (1991a) Postlabeling of the DNA binding products of anticancer agents dacarbazine and cisplatin. Human Carcinogen Exposure; pp. 329-335, IRL Press.

Mustonen, R., Försti, A., Hietanen, P. \& Hemminki, K. (1991b) Measurement by ${ }^{32}$ P-postlabelling of 7-methylguanine levels in white blood cell DNA of healthy individuals and cancer patients treated with dacarbazine and procarbazine. Human data and methods development for 7 alkyl-guanines. Carcinogenesis 12, 1423-1431.

Mustonen, R. \& Hemminki, K. (1992) 7-Methylguanine levels in DNA of smokers and nonsmokers' total white blood cells, granulocytes and lymphocytes. Carcinogenesis 13, 1951-1955.

Mustonen, R., Schoket, B. \& Hemminki, K. (1993) Smoking-related DNA adducts: ${ }^{32} \mathrm{P}$-postlabelling analysis of 7-methylguanine in human bronchial and lymphocyte DNA. Carcinogenesis 14, 151-154.

Möller, L., Grzybowska, E., Zeisig, M., Cimander, B., Hemminki, K. \& Chorąży, M. (1996) Seasonal variation of DNA adduct pattern in human lymphocytes analyzed by ${ }^{32}$ P-HPLC. Carcinogenesis 17, 61-66.

Övrebö, S., Haugen, A., Hemminki, K. \& Szyfter, K. (1994) Biological monitoring of exposure to polycyclic aromatic hydrocarbon in an electrode paste plant. J. Occup. Med. 36, 303-310.

Övrebö, S., Haugen, A., Hemminki, K., Szyfter, K., Drablös, P.A. \& Skogland, M. (1995) Studies of biomarkers in aluminum workers occupationally exposed to polycyclic aromatic hydrocarbons. Cancer Detect. Prev. 19, 258-267. 
Perera, F.P. Hemminki, K., Grzybowska, E. Motykiewicz, G., Michalska, J., Santella, R., Young, T.-L., Dickey, C., Brandt-Rauf, P., DeVivo, I., Blaner, W., Tsai, W.-Y. \& Chorąży, M. (1992) Molecular damage from environmental pollution in Poland. Nature (London) 360, 256-258.

Perera, F.P., Tang, D.L., O'Neill, J.P., Bigbee, W.L., Albertini, R.J., Santella, R., Ottman, R., Tsai, W.Y., Dickey, C., Mooney, L.A., Savela, K. \& Hemminki, K. (1993) HPRT and glycophorin A mutations in foundry workers: relationship to PAH exposure and to PAH-DNA adducts. Carcinogenesis 14, 969-973.

Perera, F.P., Dickey, C., Santella, R., O'Neill, J.P.O., Albertini, R.J., Ottman, R., Tsai, W.Y., Mooney, L.A., Savela, K. \& Hemminki, K. (1994) Carcinogen-DNA adducts and gene mutation in foundry workers with low-level exposure to polycyclic aromatic hydrocarbons. Carcinogenesis 15, 2905-2910.

Santella, R., Hemminki, K., Tang, D., Paik, M., Ottman, R., Young, T.L., Savela, K., Vodickova, L., Dickey, C., Whyatt, R. \& Perera, F.P. (1993) PAH-DNA adducts in white blood cells and urinary 1-hydroxypyrene in foundry workers. Cancer Epi. Biomarkers Prev. 2, 59-62.

Savela, K. \& Hemminki, K. (1991) DNA adducts in lymphocytes and granulocytes of smokers and nonsmokers detected by the ${ }^{32} \mathrm{P}$-postlabeling assay. Carcinogenesis 12, 503-508.

Segerbäck, D. \& Vodicka, P. (1993) Recoveries of DNA adducts of polycyclic aromatic hydrocarbons in the ${ }^{32} \mathrm{P}$-postlabelling assay. Carcinogenesis 14, 2463-2470.

Szyfter, K., Kruger, J., Ericson, P., Vaca, C., Försti, A. \& Hemminki, K. (1994a) ${ }^{32}$ P-Postlabelling analysis of DNA adducts in humans: Adduct distribution and method improvement. Mutation Res. 313, 269-276.

Szyfter, K., Hemminki, K., Szyfter, W., Szmeja, Z., Banaszewski, J. \& Yang, K. (1994b) Aromatic DNA adducts in larynx biopsies and leucocytes. Carcinogenesis 15, 2195-2199.

Szyfter, K., Hemminki, K., Szyfter, W., Szmeja, Z. \& Banaszewski, J. (1996) Tobacco smoke-associated N7-alkylguanine in DNA of larynx tissue and leucocytes. Carcinogenesis 17, 501-506.

Vaca,C.E., Vodicka, P. \& Hemminki, K. (1992) Determination of malonaldehyde-modified 2 -deoxyguanosine-3'-monophosphate and DNA by ${ }^{32} \mathrm{P}$-postlablelling. Carcinogenesis 13, 593-599.

Vodicka, P. \& Hemminki, K. (1991) ${ }^{32}$ P-Postlabeling of $\mathrm{N}-7, \mathrm{~N}^{2}$ and $\mathrm{O}^{6} 2^{\prime}$-deoxyguanosine 3 '-monophosphate adducts of styrene oxide. Chem.-Biol. Interact. 77, 39-50.

Vodicka, P., Vodickova, L. \& Hemminki, K. (1993)

${ }^{32} \mathrm{P}$-Postlabelling of DNA adducts of styrene- -exposed lamination workers. Carcinogenesis 14, 2059-2061.

Vodicka, P., Vodickova, L., Trejbalova, K., Sram, R.J. \& Hemminki, K. (1994) Persistence of $\mathrm{O}^{6}$ guanine DNA adducts in styrene-exposed lamination workers determined by ${ }^{32} \mathrm{P}$-postlabelling. Carcinogenesis 15, 1949-1953.

Vodicka, P., Bastlova, T., Vodickova, L., Peterkova, K., Lambert, B. \& Hemminki, K. (1995) Biomarkers of styrene exposure in lamination workers: Levels of $\mathrm{O}^{6}$-guanine DNA adducts, DNA strand breaks and mutant frequencies in the hypoxanthine-guanine phosphoribosyltransferase gene in T-lymphocytes. Carcinogenesis 16, 213-216.

Widłak, P., Grzybowska, E., Hemminki, K., Santella, R. \& Chorąży, M. (1996) ${ }^{32}$ P-Postlabelling of bulky human DNA adducts enriched by different methods including immunoaffinity chromatography. Chem.-Biol. Interactions 99, 99-107. 